\title{
SPATIAL PLANNING OF MOUNT VLAŠIĆ TOURIST DESTINATION
}

\author{
Ranko Mirić ${ }^{1}$ \\ Nusret Drešković ${ }^{2}$ \\ Edin Hrelja ${ }^{3}$ \\ Adnan Efendic ${ }^{4}$
}

\begin{abstract}
The main purpose of the mountain ski centers is to meet the needs of recreation and psychophysical rest. This requires large space advantage, despite the existence of various infrastructure, environmental and socio-psychological advantage that would allow recovery of human organism. However, due to the system disorganization these facilities are very often largely usurped so that their original role isignored.

One of the biggest problems for the future tourism development of Mount Vlašić is inadequate land management, which has resulted in the construction of a large number of illegal facilities that contribute to the physical and ecological burden of the mountain.

Through the paper current situation on Vlašić will be assessed, and presented natural characteristics, resources and potentials, as well as the cultural heritage of the study area. Also, analysis of the current area usage,planning organization and the environment will be carried out, applying new methodological approaches in the planning and management of space, through the significant usage of GIS.

Space organization and arrangement are viewed from the aspect of natural resources exploitation emphasising tourism development and the construction of sports, recreation and other infrastructure systems.

Main problem, is the fact that when planning the development of tourism and tourism infrastructurein the ski center Vlasic, carrying capacity, which will be, among other things, presented in the work was not taken into consideration.
\end{abstract}

Key words: spatial planning, tourist destination, environment, carrying capacity, ski center, Vlašić

\footnotetext{
${ }^{1}$ Assistant Professor, Department of Geography, Faculty of Science, University of Sarajevo, Sarajevo, Bosnia and Herzegovina. e-mail: rmiric@gmail.com

${ }_{2}^{2}$ Associate Professor, Department of Geography, Faculty of Science, University of Sarajevo, Sarajevo, Bosnia and Herzegovina. e-mail: nusret2109@gmail.com

${ }^{3}$ Teaching Assistant, Department of Geography, Faculty of Science, University of Sarajevo, Sarajevo, Bosnia and Herzegovina. e-mail: edin_hrelja@yahoo.com

${ }^{4} \mathrm{PhD}$, Federal Ministry of Spatial Planning, Sarajevo, Bosnia and Herzegovina. e-mail:

efendici@yahoo.com
} 


\section{INTRODUCTION}

With the increase in free time and free money as the two basic elements of tourism trends more and more people are involved in the tourism industry. With the development of tourism, especially without adequate spatial plan, contributes not only to employment and increase economic benefits for local people, but also to large traffic congestion, accumulation of waste, destruction of natural resources, and many social problems.

At the same time, with the development of tourism, particularly recreational forms, concept of carrying capacity was also developed, which goes in the direction of preserving nature. The methodology of determining carrying capacity, has found wide application in spatial planning, especially in planning for special purposes. The forms and intensity of human influence on the area of Vlašić substantially changed during its historical and geographical development. In the earlier development stages, Vlašić was livestock farming area where the remains from this period present complementary part of tourism. Since the 1970's, Vlašić, become tourism oriented, and since 1995 area of uncontrolled, unplanned construction for the development of ski tourism, with a number of geoecological problems.

Research on the topic addressed was carried out in three phases: first phase presents literature, statistical and cartographic data collecting, second phase analysis of the collected data and third phase synthesis of results and conclusion remarks.

\section{GEOGRAPHICAL POSITION}

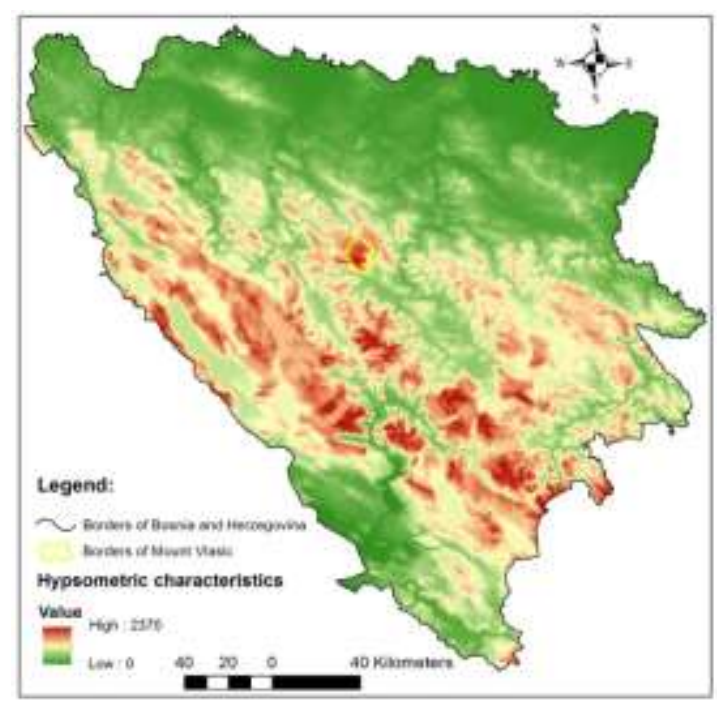

Vlašić Mountain is located in the central part of Bosnia and Herzegovina and belongs to the inner zone of the mountain Dinara system. According to the administrative organization, Vlašić is located in the Central Bosnia Canton, in the northern part of Travnik Municipality (Fig. 1). The southern border of the mountain makes the urban part of Travnik (village Krike) and Lašva River, southern River Usora, eastern border river Bila and the western mountain Čemernica.

Fig.1. Geographical position of Mount Vlašić 
Due to the central location in Bosnia and Herzegovina, Vlašić Mountain is an important crossroads of transport routes, where equally distant from the sea and from the major regional cities (Zagreb $380 \mathrm{~km}$, Split $230 \mathrm{~km}$, Belgrade $400 \mathrm{~km}$ ), and from the large regional centers of Bosnia and Herzegovina (Banja Luka $180 \mathrm{~km}, 120 \mathrm{~km}$ Sarajevo and Mostar $200 \mathrm{~km}$ ), while the town of Travnik, $28 \mathrm{~km}$ (Fig. 2).

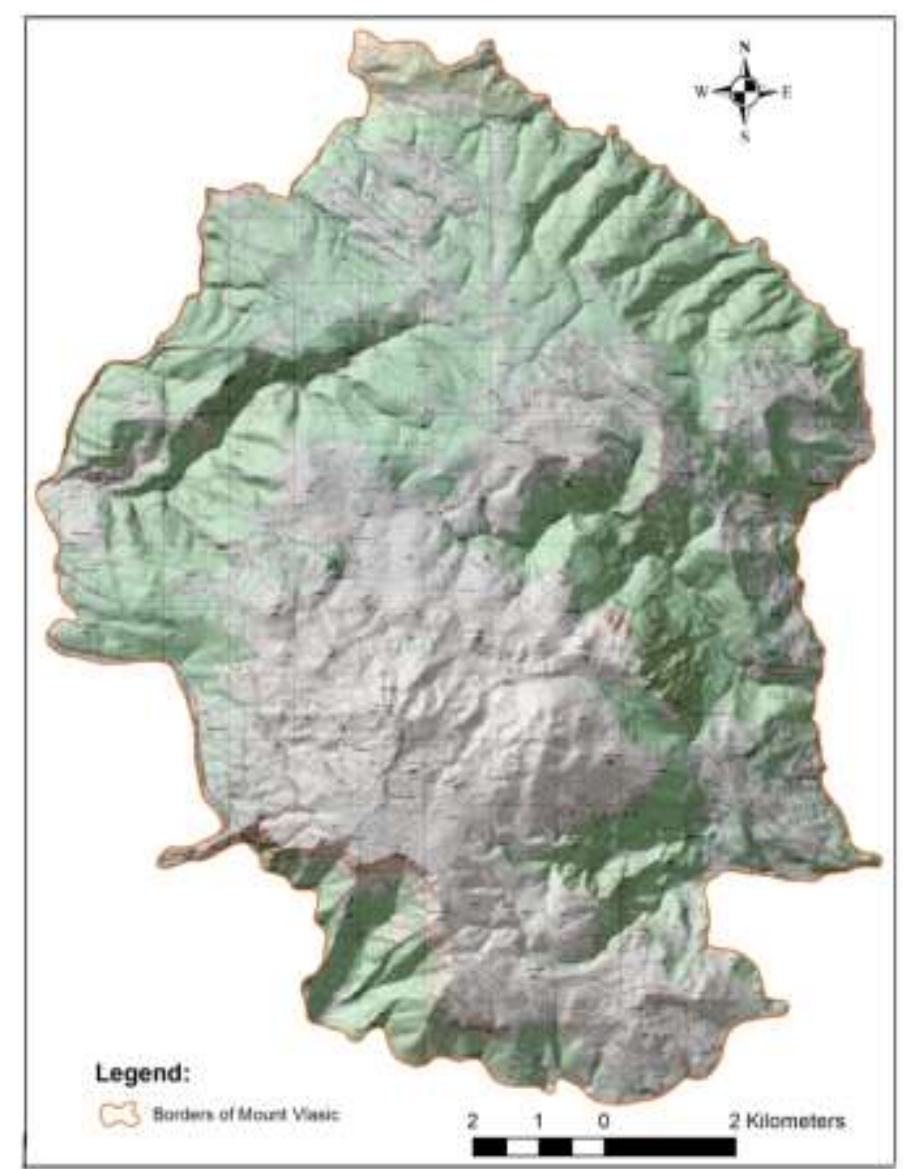

Fig. 2. Topographical map of Mount Vlašić

Vlašić in geologic terms belongs to the zone of Paleozoic and Mesozoic shales and calcite. Cretaceous and Jurassic-Cretaceous sediments have the highest distribution. Also, in smaller area carbon deposits (shale and sandstone), Miocene and OligoMiocene (clay and Sands) and fluvio-glacial and alluvial deposits (gravel, Sands) are presented.

In geomorphological terms mountain Vlašić, and its central plateau, is a large plateau with an average altitude of 1400-1500 m. Of the plateau rise numerous peaks (highest is Paljenik, $1963 \mathrm{~m}$ above sea level), Vlaška gromila (1919 m above sea level), Čavao (1817 $\mathrm{m}$ above sea level), Oštrica (1860 $\mathrm{m}$ above sea level) and others. On southern and eastern side, large number of peaks over $1000 \mathrm{~m}$ above sea level, can also be found. 
Within research area stands out and a large number relief landforms resulting from mainly karst and fluvial exogenous processes.

In terms of climate, sub-mountain climate prevails at the foot of mountains and mountain climate at higher altitudes. The average annual rainfall is in the amount of 1 $418 \mathrm{~mm}$, with an average height of snow cover of $40 \mathrm{~cm}$, which in mountain areas (above $1000 \mathrm{~m}$ above sea level) can last up to 90 days. Summers are fresh with average temperatures of the summer months below $18^{\circ} \mathrm{C}$, and winters with the lowest average temperature in January $6,8^{\circ} \mathrm{C}$.

Due to the geological structure of the study area, Vlašić mountain plateau is a poor with surface flows. The only major permanent surface flow is the river Ugar (with tributaries Ugrić, Pljačkovca, Lužnica and Dedić stream). Hydrographically, waters from central, northern and western parts of Vlašić from surface and underground drain to the upper basin of River Ugar, which flows into the Vrbas River downstream of Jajce. Southern and Eastern (river Bila) part of Vlašić, belongs to the river Lašva.

Due to natural-geographical characteristics (geological structure, hypsometric characteristics, climate characteristics) diversity and a great wealth of flora and fauna, with endemic species can be found on Vlašić. Vlašić belongs to continental Dinarides and is characterized by a wide distribution of dark coniferous forests in mountainous and sub-alpine zone, to a height of about 1700 meters above sea level. Above the belt of dark coniferous forests on the tips of Vlašić before anthropogenic influence was developed ecosystem of Coppice coniferous juniper pine, which is now completely disappeared and turned into the ecosystem of mountain meadows on limestone, or in mountain grasslands on acid soils.

\section{TOURIST TRAFFIC OF MOUNT VLAŠIĆ}

Although mountain tourism as a form of tourist movement is characterized by two seasons (winter and summer), currently on Vlašić, winter (ski) tourism is the most important.

The backbone of the tourist traffic represents Babanovac, activated in 70's when 90 meter platform was built on which international competitions in ski jumps "Vlašić Cup" were held. In the period after 1995, spontaneously, without an adequate spatial planning, Babanovac is transformed into a winter sports and recreation center. 


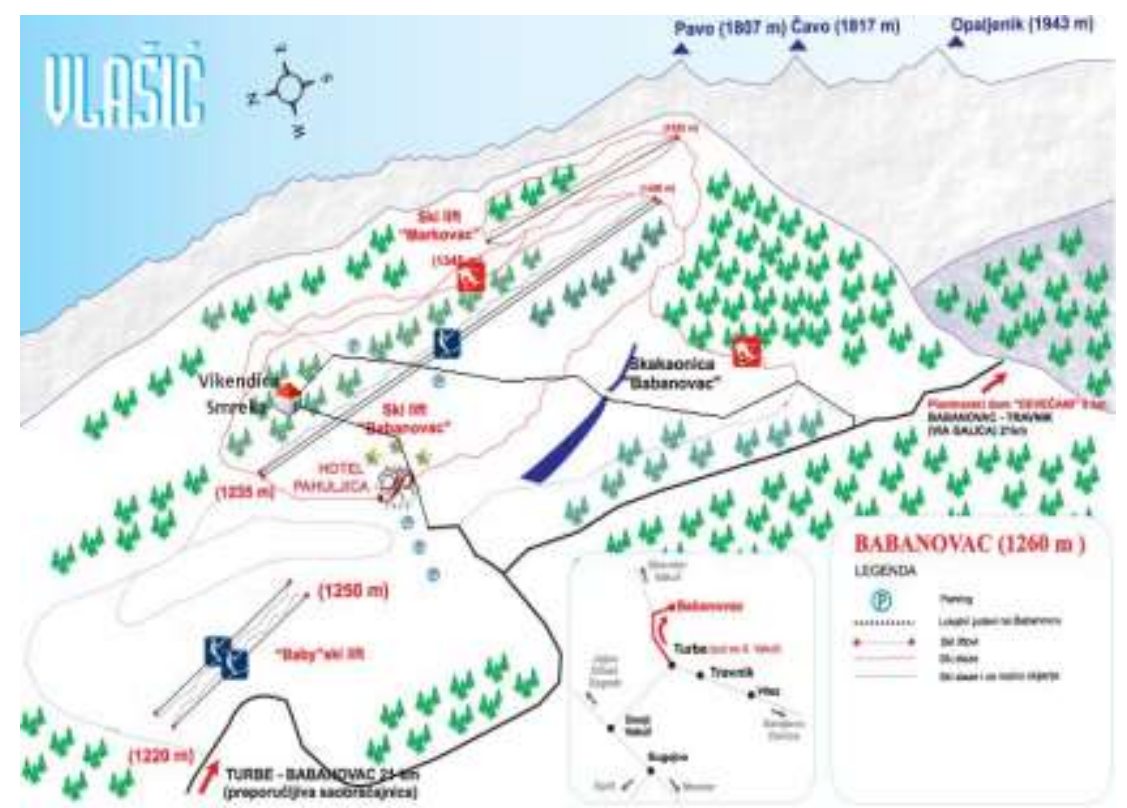

Fig. 3. Tourist map of Ski center Vlašić

Source: http://www.skiportal.hr/skijaliste/vlasic/

The biggest challenge represents an extension of the tourist season throughout the whole year for which the mountain has all the advantages. So, although Vlašić is known as a ski resort, in recent times, following the trends of tourism, other types of tourism are developed.

Developing the image of health resort, high-altitude center for the preparation of athletes, congress center, center for adventure, ecotourism, fishing and hunting, Vlašić is trying to create the image of mountain center that is active throughout the year. Also, promoting Vlašić increases number of visitors through school trips and excursions.

Table 1. Number of nights on Vlašić for 2005. and 2009.

\begin{tabular}{|c|c|}
\hline Year & Number of nights \\
\hline 2005. & 7077 \\
\hline 2009. & 8421 \\
\hline
\end{tabular}

Source: Strategija razvoja turizma općine Travnik 2011.-2015. godine,Travnik, 2011.

From the table (Tab. 1), can be concluded that in this period (2005-2009.), significant increase in number of tourists was registered, taking into accountaforementioned indicators that should be added and a large number of accommodation capacities (10.000 beds), which are not registered. The largest number of nights on Mount Vlašić was realized by tourists from Bosnia and Herzegovina and Croatia in the winter period, with the lenght of stay between 7 to 10 days. 


\section{CARRYING CAPACITY OF SKI CENTRE VLAŠIĆ}

For proper spatial planning and spatial planning for special purposes it is important to take into account the carrying capacity of the area. The carrying capacity of the ski centers are related to primarily the physical carrying capacity of the area, and ski terrain.

Under normal capacity of ski terrain is considered maximum number of skiers who can ski at the same time, not to interfere with each other. There are several categories of ski slopes capacity due to the comfort of skiers. According to some estimates, $0.1 \mathrm{ha} / \mathrm{skier}$ surface of the track is rated as comfortable capacity of $0.05 \mathrm{ha} / \mathrm{skier}$ as normal, and 0.02 ha/skier as a minimum. Capacity saturation is considered to be double the normal capacity, ie. $0,025 \mathrm{ha} / \mathrm{skier}$. Number of skiers on mountain areas is calculated so that the total number of visitors is divided by 1.3 , because it is considered that about $30 \%$ of all visitors to the ski centers are non-skiers (Martinović-Uzelac, A., 2001).

Table 2. Overview of parameters needed to calculate the carrying capacity

\begin{tabular}{|l|r|}
\hline \multicolumn{1}{|c|}{ Parametrs } & Values \\
\hline Trail surface(ha) & Cca. 50 \\
\hline Trail lengh (km) & 14 \\
\hline Average trail width (m) & 35 \\
\hline Beds in accomodation facilities & 9469 \\
\hline Parking area for daily visitors & 350 \\
\hline
\end{tabular}

Source: Ćatović, A., Hrelja, E, 2013.

According to the indicators of tourism revenues, it can be concluded that on Vlašić was 6477 skiers in this year. As the ski tourism season is expressed during two months of the year, then it can be said that on Mount Vlašić were average per day 108 skiers, or $0.46 \mathrm{ha} /$ skier on the ski slopes. When comparing standards of carrying capacity and the available surface area per skier on Mount Vlašić, one can conclude that this ski center has a category of trails that have a comfortable capacity. However, if we take into account the tourists in private accommodation who are not registered, number of nights and visitors is much higher, and therefore comfort of the ski slopes is reduced.

For the purpose of ski tourism development planning vertical transport infrastructure or capacity transport (skiers/hour) are very important. Babanovac has 5 ski lifts with a capacity of 4300 skiers/hour; in comparison with the number of tourists meets the standards of modern ski centers. However, as noted the main problem is, in the calculation are not included visitors staying in private accommodations, which contribute to the vertical transport. 


\section{INADEQUATE SPATIAL PLANNING AND PROBLEMS OF SUSTAINABLE DEVELOPMENT OF SKI CENTRE VLAŠIĆ}

Inadequate spatial planning created numerous geoecological problems caused by various factors, which relate primarily to the low level of concern for the environment, resulting in a number of shortcomings in meeting the many tourist needs. As a problem, it is primarily emphasized illegal construction of housing and other tourist facilities, during which has not taken into account the environmental carrying capacity and degradation of ambient space, which is caused by a series of psychological and physical effects on tourists.

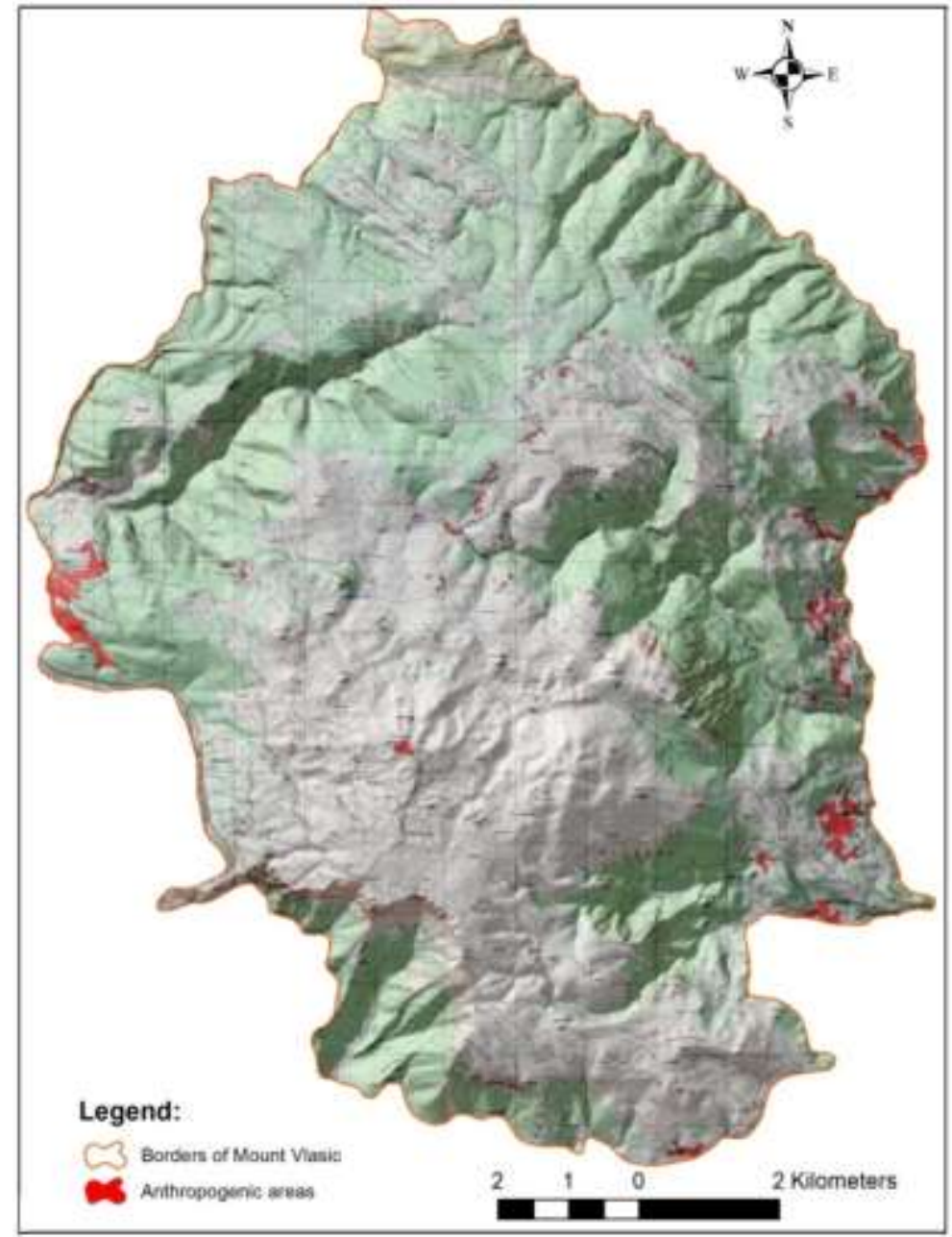

Fig.4. Anthropogenic areas on Mount Vlašić (autors)

One of the many examples of inadequate planning represents the end of the ski slopes in accommodation facilities (hotels and apartments) and recreational facilities built in front of them (Fig. 5. and 6.). 


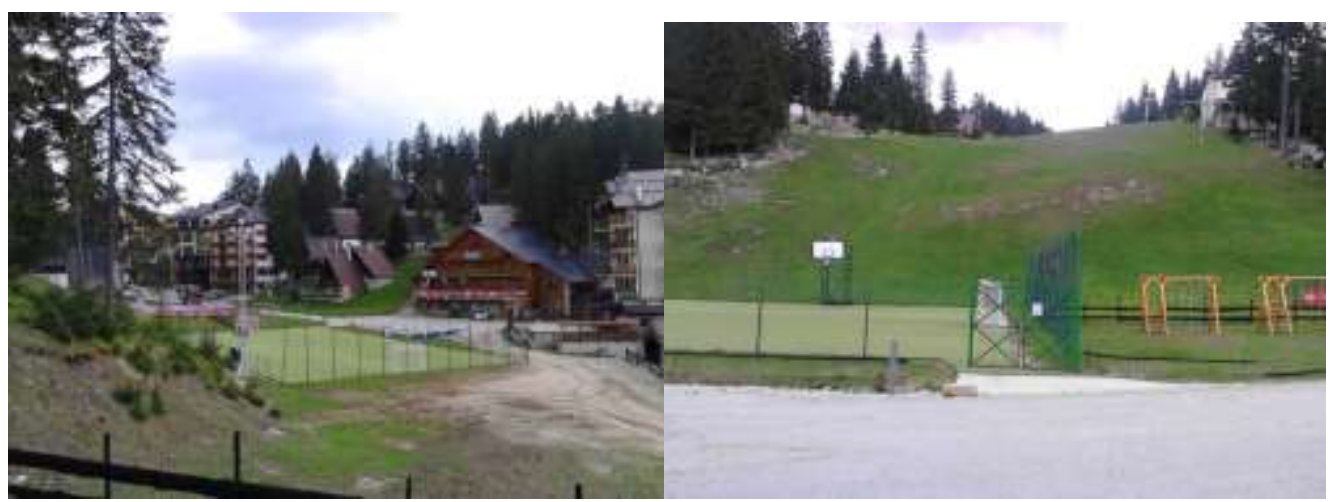

Fig. 5. and 6. End of main ski path on Babanovac

Unsupervised, "wild" and illegal construction in the end results with adequately unsolved communal infrastructure. Law on Principles of Local Self-Government, the Law on communal activities and the Statute of Travnik Municipality defined the decision on communal order in the area of the Tourist center Babanovac. Problem arises because law on communal activities is not respected. Literature and cartographic data sources and field observations, indicate that a large number of sewage pipe ends in the woods or forest streams, and even in the river Ugar. (Fig. 7. and 8.).
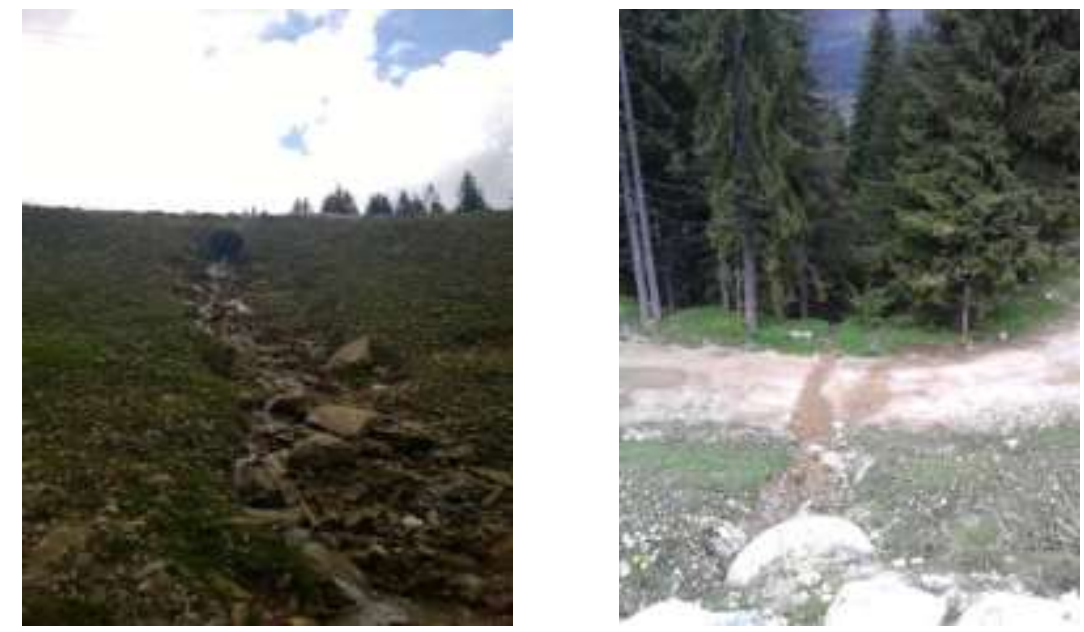

Fig. 7. and 8. Unsolved sewerage infrastructure in the Ski center Vlašić

These problems highlight the need for space management based on established spatial plans for special purposes and development strategies. Also, it is necessary to revise the existing and new legislation, and its implementation in terms of space management. Further it is necessary to carry out strict control of the number of tourists and define the limits in accordance with the carrying capacity of the area. Also, one of the measures for improving this area is the need for strengthening environmental awareness among 
local residents, local businesses and visitors, emphasizing the harmony between the natural values through the development of tourism and environmental protection.

\section{CONCLUSION}

Based on the research, it was found that Vlašić Mountain attracts large number of visitors, primarily due to naturalgeographical specificity and next to the Olympic Mountains is one of the most attractive mountains in Bosnia and Herzegovina. Also, research has found that the main concentration of tourists at Mount Vlasic is in wintertime. The main reason for such concentrated seasonal movement of tourists is the lack of complementary touristic motives, which may result in increase of tourists in the winter season. As a result of high demand of tourists in winter period (due to the favorable geographic position), everything is subordinated to satisfying their needs (construction of tourist accommodation and supporting infrastructure) in which environment is not taken into account or carrying capacity. Certainly, environmental problems contributes current political situation in Bosnia and Herzegovina, as well as lack of adequate legislation, management plans for special purposes and development strategy.

Therefore, if we want to develop sustainable tourism (that is not counterproductive and based on the principles of sustainable development), it is necessary to define stricter legislation and in accordance with it define management plans (based on carrying capacity) and strategies for sustainable development of the ski center Vlašić.

\section{REFERENCES:}

1. Ćatović, A., Hrelja, E, 2013: Vlašić mountain tourism development - problems and perspectives. Zbornik naučnog simpozijuma sa međunarodnim učešćem "Problemi i perspektive razvoja brdsko-planinskih područja" ("Problems and perspectives of hilly mountain areas") 12-15.09.2013, Ohrid, Makedonija, pp. 369-375.

2. Hrelja, E., 2016: Tourist development of Bjelasnica mountain-problems and perspective, Geografski pregled No.37, 239-247.

3. Krištofić, B., 2010: Krajolik s kapitalom u pozadini, O akterima promjena u ruralnom prostoru na primjeru općine Lovinac, Sociologija i prostor : časopis za istraživanje prostornoga i sociokulturnog razvoja,Vol. 48 No. 2 (187), 273-300.

4. Martinović-Uzelac, A., 2001: Prostorno planiranje, Zagreb.

5. Općina Travnik, 2005: Strategija razvoja općine Travnik do 2010. godine, Travnik.

6. Šiljeg, A., Šiljeg, S., Šiljković, Ž., 2010: Stanje i tendencije razvoja turističke ponude Općine Kupres (BiH), Geoadria,15 (2), 305-325.

7. http://www.skiportal.hr/skijaliste/vlasic/ 